\title{
A PROFICUIDADE DA ALTA FREQUÊNCIA NOS TRATAMENTOS ESTÉTICOS E TERAPÊUTICOS
}

\section{ARTIGO DE REVISÃo}

BESSA, Vicente Alberto Lima ${ }^{1}$

BESSA, Vicente Alberto Lima. A proficuidade da alta frequência nos tratamentos estéticos e terapêuticos. Revista Científica Multidisciplinar Núcleo do Conhecimento. Ano 04, Ed. 06, Vol. 07, pp. 116-139. Junho de 2019. ISSN: 2448-0959

\section{RESUMO}

Foi Ernst Werner von Siemens quem criou o primeiro gerador de alta frequência e hoje este equipamento tem sido utilizado na estética e na fisioterapia. Pode-se compreender a importância desse recurso eletroterapêutico a partir deste estudo, o qual objetivou analisar os fenômenos fisiológicos que podem ocorrer no corpo humano ao se empregar a alta frequência nos procedimentos estéticos e terapêuticos. Para tanto, foi realizado um estudo bibliográfico do tipo explicativo qualitativo em base de dados da Europa PMC, Pubmed/Medline, Lilacs, Scielo e Google Acadêmico. A pesquisa permitiu inferir que a terapia por alta frequência tem a capacidade de acelerar a cicatrização, destruir vírus, bactérias e fungos na superfície cutânea, além de oxigenar e nutrir os tecidos, analgesiar e agir como anti-inflamatório e facilitador de permeação de ativos. Há várias técnicas de aplicação que devem ser selecionadas de acordo com a necessidade de cada cliente. As indicações são diversas tanto no âmbito da estética quanto da terapia, porém há cuidados e ressalvas no seu emprego,

${ }^{1}$ Mestre em Ciências da Motricidade Humana; Especialização em Treinamento Desportivo e Personal Trainner; Especialização em Ginástica Médica; Especialização em Tópicos Avançados em Fisioterapia; Especialização em Fisioterapia Dermatofuncional; Especialização em Língua Poruguesa; Graduado em Fisioterapia; Tecnólogo em Estética e Cosmética,; Bacharel e Licenciado em Educação Física,; Licenciado em Letras,; Licenciado em Pedagogia. 
isto é, há casos no qual o procedimento não é recomendado. Logo, infere-se que o gerador de alta frequência é altamente benéfico ao ser humano tanto com fins estéticos quanto terapêutico se corretamente prescrito e aplicado.

Palavras-chaves: alta frequência, ozonioterapia, alta frequência+cicatrização, alta frequência+bactericida.

\section{INTRODUÇÃO}

A eletricidade tem sido amplamente utilizada como tratamento de diversos transtornos orgânicos ao longo de séculos. Ela representa uma forma de energia que pode promover mudanças na fisiologia do corpo humano durante a sua aplicação. Mudanças essas que podem gerar diversos benefícios de ordem estética e terapêutica. (ROBINSON, 2000).

O emprego da eletricidade para tratar doenças passou a ser conhecido como eletroterapia e ao longo do tempo surgiu uma infinidade de aparelhos que passaram a ser utilizados na prática médica, da educação física, da fisioterapia e na estética. Um dos equipamentos elétricos que pode ser utilizado em âmbito terapêutico e estético é o gerador de alta frequência. É sabido que esse equipamento gera corrente alternada, cujos parâmetros de frequência e tensão varia segundo o tipo de fabricante. (BORGES, 2006).

O equipamento ainda gera ozônio que é indicado no tratamento de transtornos circulatórios, pois ativa a circulação periférica local. Além de ser recomendada para desinfecção de lesões infectadas, por ter ação bactericida e propriedade antisséptica. (DAL GOBBO, 2010).

A alta frequência tem uma ação eletrosmótica que pode por osmose facilitar a permeação de substâncias nos tecidos, isto é, permeação de ativos cosméticos. (HERNANDEZ; MERCIER-FRESNEL, 1999). 
A aplicação da alta frequência contribui para a cicatrização, pois acelera a ação dos fibroblastos na produção de colágeno e desta forma promove a cicatrização estética em pessoas com lesão de primeira intenção. (MARCOS, ELIAS; PINHEIRO, 2013).

É mister destacar que o equipamento de alta frequência é comumente encontrado nos estabelecimentos de estética, em virtude do seu manuseio simples, baixo custo e eficácia constatada na prática clínica. Dessa forma, compreender os fenômenos fisiológicos e os benefícios que a aplicação da alta frequência gera no corpo humano é essencial para que o profissional possa prescrever corretamente este tipo de equipamento.

Portanto, o seu emprego necessita de cientificidade a fim de evitar erros no seu manuseio ou prescrição. Baseado no exposto surgiu à seguinte situação-problema: Quais são os efeitos fisiológicos propiciados pela terapia por alta frequência e seus benefícios estéticos e terapêuticos?

Para se desenvolver o estudo foi traçado o objetivo geral que consistiu em analisar os fenômenos fisiológicos que podem ocorrer no corpo humano ao se empregar a alta frequência nos procedimentos estéticos e terapêuticos. Além dos objetivos específicos que consistiram em: explicar os benefícios estéticos e terapêuticos propiciados pelo tratamento com alta frequência com base nos efeitos fisiológicos; descrever as técnicas de aplicação estética da alta frequência; identificar os cuidados, as indicações e contraindicações ao se aplicar à alta frequência.

O presente estudo se justificou na medida em que o uso da terapia por alta frequência é amplamente aplicado na área estética e pode promover benefícios nos tratamentos estéticos faciais, corporais e capilares. No entanto, ainda há necessidade de se investigar como fisiologicamente esses benefícios orgânicos ocorrem, pois ao conhecer esses mecanismos poder-se-á elegê-lo de forma mais segura para cada tratamento específico. Além de se evitar efeitos adversos ou complicações inesperadas. 
Este estudo foi sem dúvida relevante para todos que trabalham com Fisioterapia Dermato-funcional, para esteticistas ou para as pessoas que almejam saber mais, como a alta frequência promove diversas reações químicas e físicas que implicam em prevenção de infecções, aceleração de cicatrização, hemostasia, etc. Acrescenta-se o fato de que a compreensão do uso apropriado do equipamento de alta frequência evitará lesões nos clientes e riscos físicos no profissional.

É necessário destacar que estudos recentes não têm sido divulgados nos meios digitais, seja na língua portuguesa ou na língua inglesa, e muito pouco material data dos últimos anos. Esse fato contribui para demonstrar a relevância de se desenvolver novas pesquisas sobre a alta frequência, principalmente no campo da estética.

\section{REVISÃO DE LITERATURA}

\subsection{O GERADOR DE ALTA FREQUÊNCIA}

Ernst Werner von Siemens, nasceu em 13 de dezembro de 1816, Lenthe, Prússia atual Alemanha - e faleceu em 6 de dezembro de 1892, Charlottenburg, Berlim, Alemanha. Ele foi um engenheiro elétrico alemão que desempenhou um papel importante no desenvolvimento do telégrafo de ponteiro, do elevador elétrico, do fotômetro de selênio, do gerador elétrico e do dínamo elétrico de corrente alternada. Além disso, ele foi o construtor das primeiras linhas de telégrafo da Europa e um dos fundadores do conglomerado Siemens Aktiengesellschaft, ou simplesmente Siemens AG, que é um conglomerado industrial alemão, sendo o maior da Europa e um dos maiores do mundo. (The Editors of Encyclopaedia Britannica, 2018). Portanto, foi Siemens quem criou o primeiro gerador de alta frequência $(\mathrm{HF}$, do inglês high frequency) em 1957.

Num momento posterior, Kleinmann pesquisou a eficiência do gerador de alta frequência para inibir a flora bacteriana através de testes em mucosas de animais e humanos. (BARROS; SANTOS; BORGES, 2007). Desde então, vários trabalhos têm sido feitos para verificar os efeitos que esse equipamento pode ter em âmbito médico, fisioterapêutico e estético. 
Sabe-se que o equipamento possui diferentes tipos de eletrodos de vidro preenchidos com gás ou ar rarefeito. Quando a corrente elétrica alcança o eletrodo, haverá ionização das moléculas do gás formando o ozônio na superfície do eletrodo (MARTINS, A. et. al., 2012). Logo, o equipamento gerador de alta frequência produz uma corrente alternada de baixa intensidade e alta tensão que ao passar por diferentes tipos de eletrodos de vidro gera ozônio (KARELO, 2013).

Esse equipamento utiliza as correntes alternadas, sendo que os gases argón, xenon ou neon entram em contato com o oxigênio do ar e o transforma em ozônio. Os principais efeitos fisiológicos são: térmico, hiperemia e vasodilatação, aumento da oxigenação celular, ação bactericida e antisséptica e melhora do trofismo dérmico (OLIVEIRA; PEREZ, 2008).

O ozônio por ser uma molécula instável é decomposta facialmente em oxigênio molecular $\left(\mathrm{O}_{2}\right)$ e oxigênio atômico $(\mathrm{O})$. É sabido que o ozônio tem ação desinfectante graças ao efeito do oxigênio atômico liberado durante a decomposição. (BARROS; SANTOS; BORGES, 2007).

É mister destacar que a corrente de alta frequência ao atravessar o eletrodo pode adquirir várias tonalidades de acordo com o tipo de gás contido no eletrodo. Se o conteúdo do eletrodo for o vácuo à corrente assume uma luminescência azulada, já na presença de gás neón, a corrente assume uma tonalidade alaranjada (SORIANO; PÉREZ; BAQUÉS, 2002).

É sabido que a corrente alternada do gerador de alta frequência possui uma frequência que pode variar de 150 a $200 \mathrm{kHz}$ e uma tensão de $30 \mathrm{mil}$ a 40 mil volts. Esse aparelho gera um campo elétrico que tem capacidade de determinar alterações fisiológicas com efeitos imediatos na prática clínica, possivelmente por sua ação bactericida, antisséptica e anti-inflamatória, as quais podem beneficiar a reparação tecidual. (OLIVEIRA, 2011).

Os benefícios estéticos e terapêuticos propiciados pelo tratamento com alta frequência são vastos, pois se adiciona os efeitos da eletroterapia aos da 
ozonioterapia. Visto que é sabido que a ozonioterapia poderá intervir no equilíbrio de óxido-redução, por isso ela tem sido muito explorada no tratamento de doenças agudas e crônicas. Pode-se obter o ozônio através do equipamento gerador de alta frequência, o qual vem sendo largamente utilizado no tratamento de afecções de pele, acelerando o processo de cicatrização de feridas cutâneas. (Pereira Sá, 2010).

\subsection{OS BENEFÍCIOS ESTÉTICOS E TERAPÊUTICOS PROPICIADOS PELO TRATAMENTO COM ALTA FREQUÊNCIA}

A ozonioterapia pode ser empregada em todos os tipos de pele e é vasto o seu emprego como germicida ou bactericida. O gás ozônio é considerado uma forma instável do oxigênio, tendo as mesmas propriedades deste, entretanto bem mais energético. (PEREIRA, 2007).

Um estudo sobre a aplicação de ozonioterapia em pacientes com enfisema pulmonar foi realizado para avaliar os efeitos da terapia com ozônio retal em pacientes com enfisema pulmonar. Para tanto, foram aleatoriamente designados 64 pacientes entre 40 e 69 anos com enfisema pulmonar que se submeteram a 20 sessões diárias com oxigênio medicinal retal ou sem tratamento. Para avaliar o resultado, os voluntários foram submetidos no início e no final do estudo a avaliação clínica e a espirometria. Cinquenta voluntários completaram o protocolo, 20 receberam terapia com ozônio, 20 receberam oxigênio retal e 10 não receberam nenhuma terapia. Concluíram que os voluntários que receberam a terapia com ozônio tiveram valores significativamente menores de volume expiratório forçado no primeiro segundo (fEV1) e fEV1 / capacidade vital forçada, logo a terapia com ozônio retal pode ser útil em pacientes com enfisema pulmonar (Calunga, 2011). Este fato comprova que ozonioterapia pode estimular sistemas antioxidantes e proteger contra os radicais livres e melhorar a ventilação pulmonar.

Vários estudos têm sido feitos para verificar os efeitos do equipamento de HF, dentre eles, o seu efeito no tratamento de onicomicoses de três pacientes. Nesse estudo, foi feita coleta de material subungueal para análise micológica, isto é, exame direto e cultura. Depois foram feitas aplicações de HF semanais sobre a lâmina ungueal 
durante 12 meses, sendo que mensalmente eram realizadas novas análises. Antes de iniciar as sessões de HF, os três examinados apresentavam exame positivo para Trichophyton rubrum e um deles também tinha positividade para Candida. Embora o resultado se mantivesse positivo durante todo o tratamento, constatou-se uma inibição do crescimento fúngico em cultura. Quanto ao aspecto clínico e estético das unhas, teve melhora no formato e coloração e não houve efeitos colaterais. (DA SILVA; FARIA, 2011).

Outra pesquisa realizada para verificar a ação antimicrobiana do uso de HF foi um estudo de caso de uma paciente com verruga ungueal vulgar, na qual foi aplicado durante 15 minutos a HF por 3 vezes ao dia e durante 3 meses. Para tanto, foi utilizada a técnica de faiscamento. $O$ acompanhamento foi realizado através de fotometria no início e ao final do tratamento. O resultado culminou com a regeneração tecidual completa no local da lesão, desaparecendo o amarelado da lâmina ungueal e não deixando sequelas de deformação (BARROS; SANTOS; BORGES, 2007).

A fim de verificar o efeito bactericida do gerador de HF sobre a cultura do Staphylococcus aureus foi realizado um estudo analítico experimental in vitro. Para tanto, foram inoculadas 36 placas de Petri com Staphylococcus aureus e dividida em 6 grupos com 6 placas. Dois grupos foram usados como controle e não receberam intervenção. Desses, um grupo foi usado para controle dos grupos tratados 5 vezes na semana; outro para os tratados 3 vezes na semana. Sendo que 4 grupos foram tratados, sendo 2 grupos tratados 5 vezes por semana por 10 e 15 minutos, respectivamente. Outros 2 grupos foram tratados 3 vezes por semana por 10 e 15 minutos, respectivamente. Todos os 4 grupos receberam um total de 15 intervenções de HF. Ao término foi realizada a replicagem em placas de Petri estéreis e após 48 horas, elas foram fotografadas para verificar se houve proliferação bacteriana. $O$ estudo permitiu inferir que a frequência de 5 vezes semanal durante 15 minutos teve o melhor efeito bacteriano. (MARTINS et. al., 2012).

Estudo semelhante realizado no Laboratório de Microbiologia da Faculdade AngloAmericano em Foz do Iguaçu, Paraná, um estudo analítico experimental in vitro com uso do gerador de alta frequência em cultura de Staphylococcus aureus. O 
objetivo da pesquisa foi verificar o efeito bactericida do gerador de alta frequência sobre a cultura de $\mathrm{S}$. aureus. Para tanto, 36 placas de Petri foram inoculadas com bactéria e foram divididas em 6 grupos: 4 tratados e 2 controles (GC3 e GC5). Duas placas (G5- 15 e o G5-10) foram tratadas 5 vezes por semana durante 15 e 10 minutos, respectivamente; já outras duas (G3-15 e o G3-10) foram tratados 3 vezes por semana durante 15 e 10 minutos, respectivamente. No tratamento foi utilizado o aparelho de alta frequência pela técnica de faiscamento com eletrodo standard e na intensidade 10. As placas foram observadas e fotografadas com o objetivo de se verificar a ocorrência de proliferação das bactérias. O estudo permitiu se inferir que o aparelho teve efeito bactericida após 15 intervenções, em uma frequência semanal de 5 aplicações, com tempo de exposição diária de 15 minutos. (Marquetti; ruaro; fréz, 2012)

A HF também foi utilizada em estudos para investigar o seu efeito sobre a dor e cicatrização de úlceras de pressão. Foi realizado um estudo piloto de ensaio clínico em 8 pacientes com graus II e III de úlceras de pressão que estavam internados em UTI. Os voluntários foram divididos em 2 grupos, sendo 2 pacientes para controle e 6 pacientes submetidos a sessões diárias de HF por 10 dias. A técnica usada foi o faiscamento com amplitude a $80 \%$ no entorno da úlcera e seu interior. No total foram aplicadas 10 sessões diárias no tempo máximo de acordo com as dimensões de lesão (1 minuto para cada $\mathrm{cm}^{2}$ ), num total de 2 semanas de intervenção. A dor foi avaliada pela escala visual analógica para dor e a cicatrização pela PUSH (Pressure Ulcer Scale for Healing) tool, PSST (Pressure Sore Status Tool) e área de superfície da úlcera pela planimetria e imagem. O estudo constatou que houve diferença significativa entre os grupos de controle e submetidos à HF. Foi constatada a melhora na cicatrização e no quadro de dor. (KARELO, 2013).

Outra pesquisa realizada para tratamento de úlcera de pressão através da HF teve objetivo de demonstrar seu benefício por intermédio de revisão de literatura. Os autores concluíram que a HF pode ser utilizada no tratamento de vários tipos de lesões cutâneas, dentre elas a úlcera de pressão. A técnica foi considerada segura, de fácil manuseio e baixo custo. (OLIVEIRA, L.M.N., 2011). 
Foi realizado um estudo experimental em 24 ratos Wistares, nos quais foram feitas feridas cutâneas de $8 \mathrm{~mm}$ de diâmetro. Em seguida, os animais foram separados em quatro grupos: A, controle; $\mathrm{B}$, laser GaAllnP; $\mathrm{C}$, gerador de alta frequência, e $\mathrm{D}$, laser GaAllnP + gerador de alta frequência. Os equipamentos foram: o laser GaAllnP de $670 \mathrm{~nm}, 6 \mathrm{~J} / \mathrm{cm}^{2}$ e 120 segundos e o gerador de alta frequência com intensidade de $80 \%$ e 120 segundos. O estudo objetivou avaliar a ação do laser GaAllnP e do gerador de alta frequência no tratamento de feridas cutâneas. Pode-se concluir que a terapêutica combinada (laser GaAllnP + gerador de alta frequência) foi a mais eficaz para abreviação do processo cicatrical. (Pereira Sá, 2010).

Investigar os efeitos no tratamento de lesão por pressão sobre o tamanho e tempo de cicatrização, com a utilização do gerador de alta frequência, em idosos acometidos por doenças neurológicas. A metodologia de estudo foi descritiva, exploratória, do tipo pesquisa de intervenção não farmacológica, a qual foi realizada em uma Unidade de Reabilitação Física, em ljuí, no noroeste do Rio Grande do Sul. Foram selecionados, intencionalmente, três homens idosos, sedentários, com diagnóstico clínico de lesão por pressão nos estágios II ou III e em tratamento clínico. A avaliação das lesões foi realizada com base nos aparência das feridas, nas características e no grau de classificação, em conformidade com a National Pressure Ulcer Advisory Panel, que abarcou três dimensões: tipo de tecido, quantidade de exsudado e área da lesão. Dois voluntários foram submetidos a 16 sessões com duração de 15 minutos e um voluntário foi submetido a 13 sessões com duração de 15 minutos, pois ocorreu cicatrização. Ao final das sessões, em dois usuários ocorreu a cicatrização completa e, no terceiro, parcialmente. $O$ estudo permitiu concluir que a terapia por alta frequência é efetiva no tratamento de lesão por pressão. (ALMEIDA. et al., 2017).

Um estudo realizado sobre a aplicação da alta frequência, do laser e da microcorrente objetivou demonstrar os efeitos da associação desses três recursos no tratamento do reparo tecidual em lesão por pressão. Como metodologia foi feito um estudo de caso de um homem lesionado medular de 25 anos que possuía lesão de pressão em estágio 4, em virtude de longo período de acamamento ou de sedestação na cadeira de rodas. O voluntário foi tratado na clínica FisioUnisc da Universidade de Santa Cruz 
do Sul e foi submetido a uma avaliação para coleta de dados demográficos e clínicos. Para tanto, foi utilizado o Instrumento de Avaliação do Estado da Lesão de Pressão proposto por Barbara Bates-Jensen e a Classificação das Lesões por Pressão por Estágios. No voluntário, foi aplicado 10 minutos de alta frequência com eletrodo cogumelo pequeno varrendo toda superfície da lesão. Posteriormente, foi aplicada a microcorrente durante 25 minutos, com frequência de $600 \mathrm{~Hz}$ com dois canais distribuídos em forma de cruz com $100 \mathrm{~Hz}$ de intensidade em cada um. Na sessão seguinte, foi repetida a aplicação da alta frequência seguida do laser de baixa potência no modo pontual com intensidade de $12{\mathrm{~J} \mathrm{~cm}^{2}}^{2}$ pelo tempo determinado pelo equipamento para cada ponto, com emissão de feixe contínuo, $660 \mathrm{~nm}$ de comprimento de onda. O procedimento foi mantido por 15 sessões, 3 vezes por semana de forma alternada. O resultado final obtido foi a redução de $81 \%$ do tamanho da lesão de pressão, o que mostrou resultados satisfatórios. (SCHUH, 2017).

Foi realizado um estudo com o objetivo de verificar a eficácia e esclarecer os mecanismos subjacentes do tratamento com oxigênio-ozônio nas DFUs (úlceras do pé diabético). Cinquenta voluntários diabéticos tipo 2 complicados com DFUs foram divididos em 2 grupos: um grupo controle tratado apenas por terapia padrão e grupo tratado com ozonioterapia padrão mais tratamento com oxigênio-ozônio. A ferida foi medida e foram realizadas biópsias teciduais no início e final. Foram determinados exames imuno-histoquímicos de expressões do fator de crescimento endotelial vascular (VEGF), fator de transformação do crescimento $\beta$ (TGF- $\beta$ ), e proteínas de fator de crescimento derivado de plaquetas (PDGF) nos espécimes patológicos. Podese concluir que a ozonioterapia promoveu a cicatrização de feridas nas DFUs através da potencial indução de VEGF, TGF-p e PDGF na fase inicial do tratamento. (Zhang et al, 2014).

O uso de alta frequência tem sido empregado no pós-operatório da abdominoplastia e da rinoplastia em virtude do auxílio da oxigenação do tecido e pelo seu efeito bactericida. Nesses casos, recomenda-se a utilização de uma gaze sobre a pele durante a aplicação da alta frequência para facilitar o deslizamento e diminuir a incidência da corrente direta sobre a pele. (MAUAD, 2003). 
Em função do seu efeito anti-microbiano sobre vírus, fungos e bactérias, o equipamento de HF tem sido amplamente utilizado nas áreas de fisioterapia e estética. Além do efeito anti-microbiano, a HF tem propiciado a melhora no processo de nutrição e oxigenação dos tecidos, analgesia, cicatrização e efeito anti-inflamatório e por isso tem sido recomendada em tratamentos estéticos capilares, faciais e de podologia. (BORGES, 2006).

O uso da alta frequência colabora na limpeza de pele, na terapia capilar melhorando a circulação do couro cabeludo, na cicatrização das lesões originadas pelas acnes, beneficia o processo de reparação da pele, e facilita a ionização indireta de substâncias, como ampolas aquosas nutritivas a base de colágeno. (SANTOS; GUIMARÃES, 2008).

A HF tem efeitos anti-microbiano, acelera a cicatrização, propicia a analgesia, melhora a oxigenação e nutrição dos tecidos graças aos efeitos térmico e vasodilatador, além de ser anti-inflamatória, por isso ela tem sido utilizada tanto para tratamento médico quanto nos procedimentos de Fisioterapia Dermato-funcional e estética, dentre eles: após procedimentos de podologia, pós-epilação, desinfecção pós-extração de comedões, em terapia capilar de alopecia e seborreia, cauterização de pele pósextração de pústulas, facilitar a permeação de ativos etc. (IBRAMED, 2012).

Foi realizado um estudo sobre a aplicação da alta frequência no tratamento da acne, cujo objetivo foi avaliar a efetividade da corrente de alta frequência no tratamento das acnes vulgaris de graus I e II em fisioterapia dermato-funcional. A metodologia foi do tipo ensaio clínico, não controlado, exploratório, no qual participaram 50 voluntárias com idade de 18 a 25 anos do sexo feminino, as quais foram avaliadas e submetidas a 8 sessões de alta frequência, 2 vezes por semana, com 1 hora de atendimento. As voluntárias responderam ao final no tratamento que aumentaram a sua autoestima e estavam muito satisfeitas com os resultados do tratamento. $O$ estudo afirma que a alta frequência faz a desinfecção após a extração de eflorescências acneicas. (Rodrigues, 2014). 
Foi realizado um estudo de ensaio clínico, prospectivo, descritivo e experimental que teve como objetivo realizar e avaliar a eficácia de um protocolo para pele acneica que foi preparado pela Medicatriz associado ao vapor de ozônio e ao aparelho de alta frequência. Foi feito acompanhamento fotográficos e avaliação visual. A alta frequência foi utilizada antes da aplicação da máscara de argila em todas as sessões do tratamento da pele acneica para obter efeito antibactericida, antifungicida e antiséptico. O resultado do protocolo permitiu concluir que houve a redução das lesões inflamatórias, textura e diminuição da oleosidade da pele. (SILVA; PEREIRA, 2018).

Foi realizada uma pesquisa cujo objetivo era revisar a literatura em relação aos fatores causais e tratamentos tópicos utilizados para a acne. A metodologia adotada foi uma revisão bibliográfica nos últimos dez anos em bases de dados como SCIELO, LILLACS e PUBMED. Os autores concluíram sobre a importância do tratamento através substâncias tópicas (retinoides, peróxido de benzoíla, nicotinamida, ácido azelaico, azeloglicina e antibióticos tópicos) em pessoas com acne nos graus leves e moderados, assim como medicação de uso oral. E relataram que há um vasto arsenal de tratamento de comedões abertos, pápulas e pústulas que vão do peeling químico, microdermoabrasão, laserterapia até os equipamentos de eletroterapia, como alta frequência e de baixa potência. É mister ressaltar que os autores salientaram que é essencial associar o gerador de alta frequência nas sessões de extração dos comedões para prevenir infecções. (DEUSCHLE et al., 2015).

\subsection{AS TÉCNICAS DE APLICAÇÃO ESTÉTICA DA ALTA FREQUÊNCIA}

Para aplicar a terapia de alta frequência é necessário conhecer o equipamento, incluindo os seus componentes, assim como as técnicas de aplicação. Dessa forma, é possível eleger a conduta mais apropriada, portanto é necessário descrever as técnicas de aplicação estética da terapia de alta frequência.

Sabe-se que o aparelho de alta frequência possui diferentes tipos de eletrodos constituídos por um tubo de vidro a vácuo ou contendo gás especial que se fixam a 
uma bobina, o que permite a adaptação às diferentes regiões corporais nas quais serão aplicados. (SORIANO; PÉREZ; BAQUÉS, 2002).

O tempo de utilização depende do local e do tipo da aplicação, que é, na maioria das vezes, em aproximadamente de três a dez minutos. Sendo que a intensidade adotada deve ser suficiente para gerar faiscamento, porém respeitando a sensibilidade do cliente. A desinfecção dos eletrodos após o uso deve ser feita com um papel, ou pano limpo com álcool a 70\%. (OLIVEIRA; PEREZ, 2008).

O equipamento dependendo do fabricante pode ser bivolt ou possui uma chave comutadora 110/220 volts. Os componentes desse tipo de aparelho são bem semelhantes e podem ser encontrados descritos nos manuais de instruções fornecidos pela empresa fabricante. No manual da IBRAMED (2012) é possível encontrar cada componente do aparelho de alta frequência, a saber:

1. Caneta HF aplicadora de alta frequência;

2. Chave liga desliga e controle de intensidade da alta frequência;

3. Cabo da caneta HF;

4. Fonte de alimentação do equipamento;

5. Saída do cabo da caneta HF;

6. Chave comutadora $110 / 220$ volts;

7. Pinos de conexão da fonte de alimentação na tomada de rede elétrica;

8. Fusível de proteção.

É bom destacar que a numeração corresponde a cada componente apresentado na figura 1. 
Figura 1: Componentes do aparelho de HF

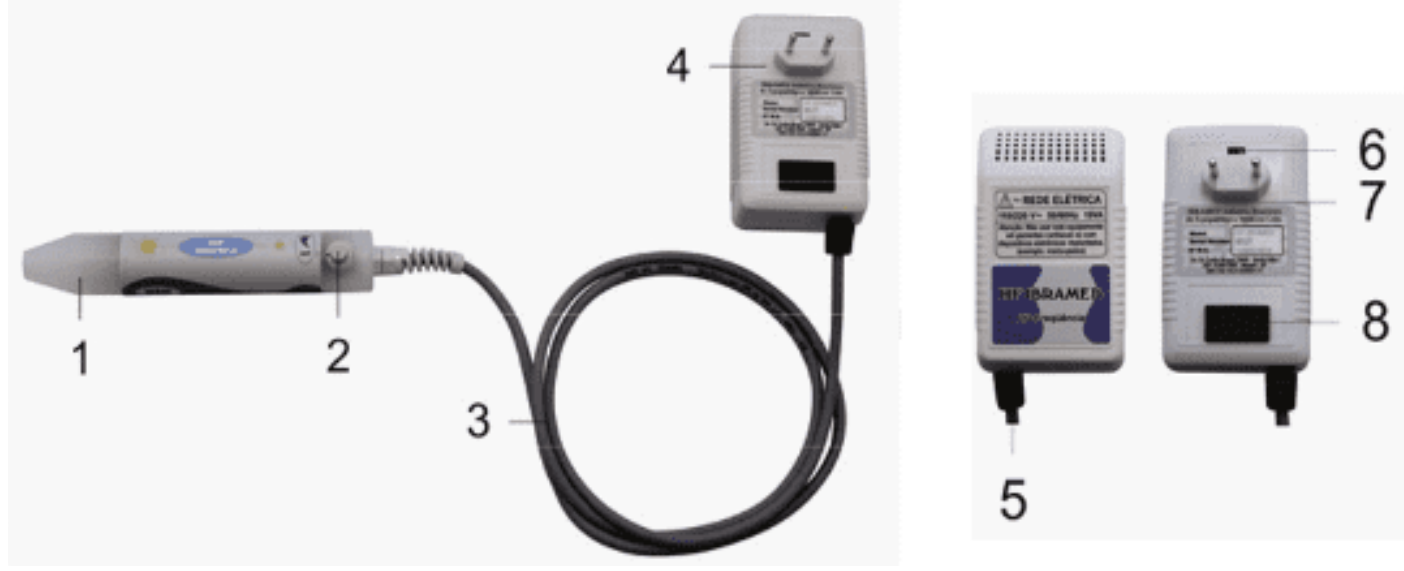

Fonte: IBRAMED, 2012.

Para a aplicação da terapia por alta frequência é usada uma caneta denominada de caneta de HF e nela é que são conectados os eletrodos de vidro. Há distintos tipos de eletrodos de vidro para se adaptarem a superfície corporal do cliente e para atender aos tratamentos faciais, corporais, capilares e podologia. É mister ressaltar que todos os eletrodos possuem a mesma função, sendo que o distinto formato tem meramente uma função anatômica. Os eletrodos devem ser higienizados unicamente com pano ou lenço de papel limpo segundo o Manual do Equipamento da IBRAMED (2012).

Figura 2: Eletrodo de vidro e caneta de HF
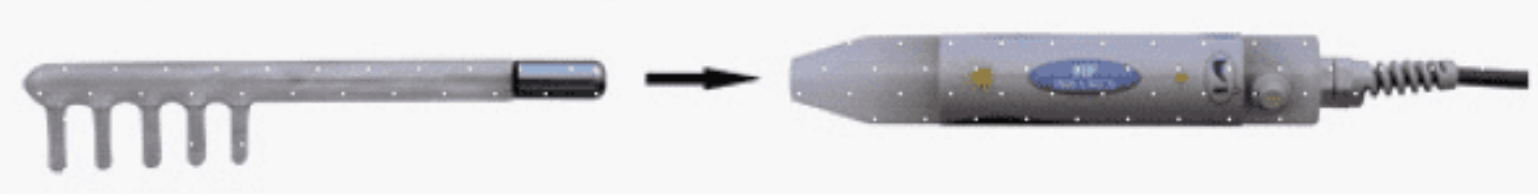

Fonte: IBRAMED, 2012

Os tipos de eletrodos mais frequentes utilizados na terapia por alta frequência são: 1 . eletrodo tipo forquilha; 2. standart pequeno (ou cebolinha ou esférico menor); 3. tipo saturador; 4. tipo cauterizador (ou cautelizador); 5. standart grande (cebolão ou 
esférico maior); 6. tipo pente. É apropriado enfatizar que a numeração descrita obedece a cada componente apresentado na figura 3.

Figura 3: Eletrodos de vidro mais usados

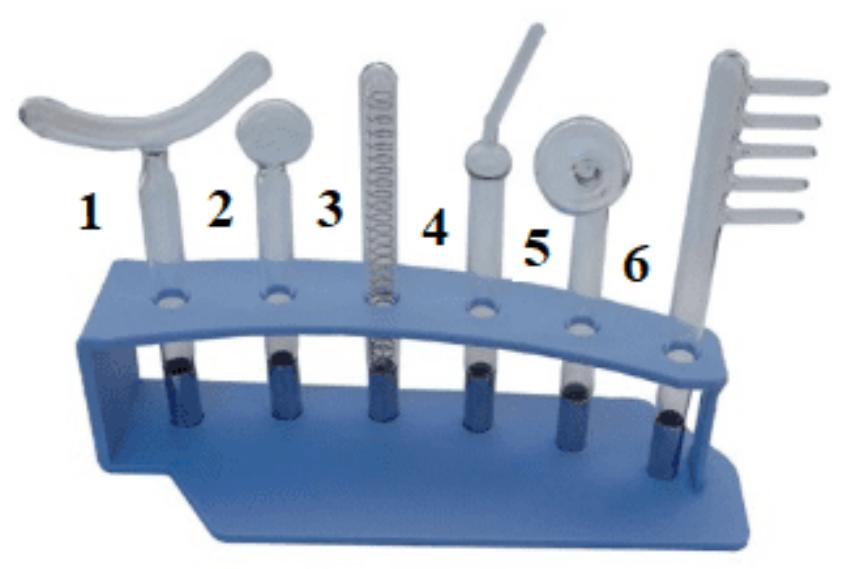

Fonte: o autor, 2019

Há eletrodos menos utilizados, porém com suas peculiaridades e igual eficiência terapêutica, são eles: 1. eletrodo tipo rolete; 2. tipo cachimbinho; 3. cachimbo médio; 4. cachimbo grande; 5. rabo de peixe (ou rabo de baleia); 6. tipo língua; 7. tipo cogumelo; 8. tipo chuveiro; eletrodo conjugado $3 \mathrm{em} 1$. Porém, é preciso destacar que os diferentes modelos de eletrodos servem para melhor adaptação a superfície corporal do cliente. 
Figura 4: Outros tipos de eletrodos de vidro
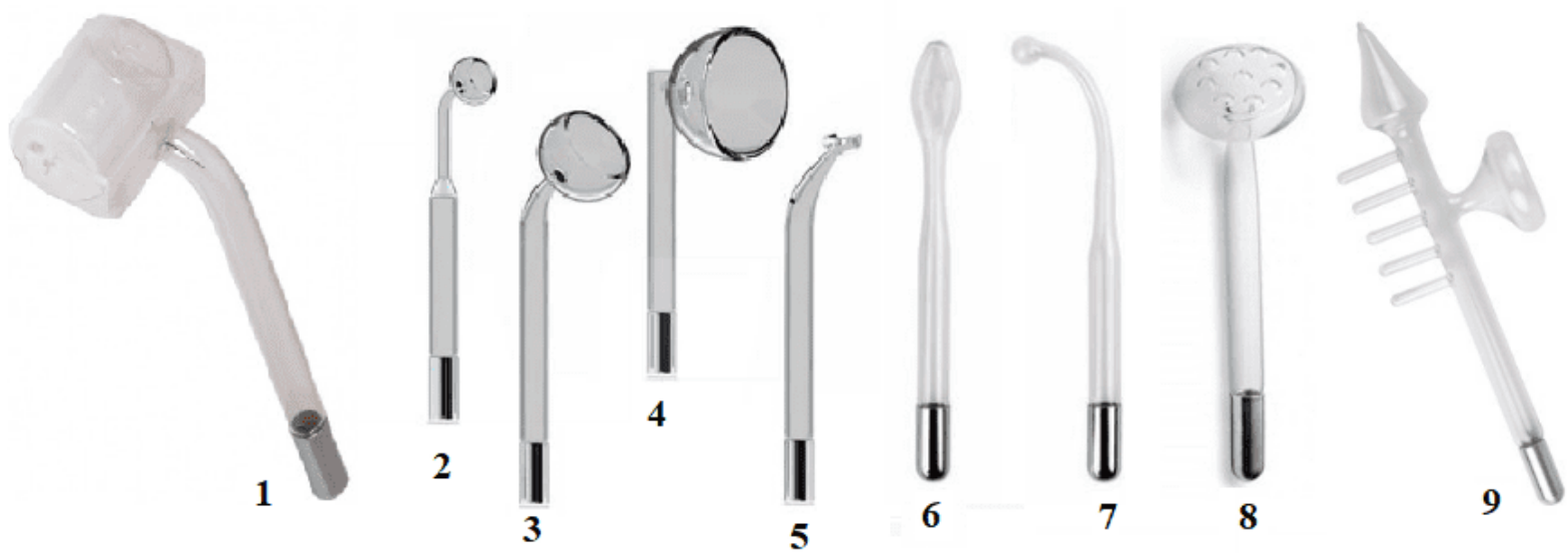

Fonte: o autor, 2019

As técnicas de aplicação da terapia de alta frequência podem ser basicamente divididas em quatro tipos: fluxação, faiscamento direto, fulguração e faiscamento indireto (SORIANO; PÉREZ; BAQUÉS, 2002; HIDROSUX [201?]).

A fluxação ou efluviação é uma técnica na qual o eletrodo é passado de forma lenta sobre a superfície plana e em contato direto sobre a pele bem seca para melhor atuação do ozônio. Antes de encostar o eletrodo no cliente, o profissional deve colocar o seu dedo na extremidade do eletrodo e retirá-lo somente depois do contato com a pele do cliente. Ao término do tratamento, retirada do eletrodo se procede colocando o dedo na extremidade do eletrodo e retirando ele de contato com a pele do cliente (DAL GOBBO, 2010). É contraindicado o uso de cosméticos, papel ou gaze nesta técnica de aplicação. Essa técnica é recomendada em casos de pós-epilação facial e corporal como profilaxia, tratamento capilar com eletrodo pente (peles seborreias), após limpeza de pele facial (peles acneicas). Os eletrodos mais utilizados nessa técnica são standarts pequeno e grande e o tipo forquilha, sendo que este último além de ser empregado pós-epilações no corpo, é também é usado para relaxamento da cervical.

O faiscamento direto é uma técnica na qual o eletrodo fica um pouco afastado da pele do cliente a fim de provocar faíscas. Nesse caso, há a formação de ozônio e haverá 
um efeito de hiperemia e estimulação, com ação antisséptica e por isso, ela é uma técnica indicada pós-epilação, após extração de comedões e pústulas e também para peles átonas e desvitalizadas.

A fulguração é uma variação da técnica de faiscamento direto e nesta técnica se obtêm a formação do ozônio que facilitará a cicatrização e o efeito homeostático (estancamento de sangue), após a drenagem de pústulas, pequenos sangramentos pós-epilação, feridas ungueais após retirada de cutícula. Para sua aplicação se usa o eletrodo de vidro tipo cauterizador, o qual fica a uma curta distância da pele (milímetros), todavia sem encostá-lo em nenhum momento.

A última técnica é o faiscamento indireto que é uma técnica exclusiva para eletrodo saturador. Ela tem uma ação tonificante no sistema neuromuscular, o cliente deverá segurar o eletrodo de vidro em uma mão e a bobina (porta-eletrodo) na outra mão, enquanto o profissional realiza um suave tamborilamento sobre a pele do cliente ou faz massagem na região a ser tratada. É o único que pode ter uso cosmético, por isso ele é recomendado para permeação de ativos cosméticos como óleos, cremes nutritivos, visto que este procedimento também tem a propriedade de aumentar a vascularização da pele. Recomenda-se que o tempo de aplicação dessa técnica seja de 3 minutos, porém quando a pele estiver muito desvitalizada, pode-se aplicar no máximo 5 minutos (DAL GOBBO, 2010).

\subsection{CUIDADOS, INDICAÇÕES E CONTRAINDICAÇÕES AO SE APLICAR À ALTA FREQUÊNCIA}

A terapia de alta frequência pode ser usada como complemento na hidratação tecidual e revitalização facial; antisséptico após procedimentos cirúrgicos; após a limpeza de pele (tratamento da pele acneica); cauterização de pústolas; desinfecção do couro cabeludo; peticulose; alopecia; dermatite seborreica; pós-epilação; foliculite; psoríase; tratamento de frieiras e micoses na podologia; após extração de eponíquio na manicure e pedicure; feridas abertas; úlcera de pressão infectadas; pode ser usada com cuidado em pessoas portadoras de rosácea; e para permeação de ativos ionizáveis. 
As principais contraindicações são: marca-passo cardíaco, alterações de sensibilidade, pele com produtos inflamáveis, neoplasias (câncer) e gestantes (OLIVEIRA; PEREZ, 2008). Há também contraindicações em clientes com trombose venosa profunda, alergia à corrente, insuficiências renal e cardíaca, hipertensos e diabéticos descompensados. Se o cliente usar aparelhos auditivos, deverá tirá-lo, pois eles podem ser danificados ou desregulados pelo equipamento de alta frequência. Ele também não é recomendado para pessoas portadoras de epiléticos e com pinos ou placas metálicas no local da aplicação e cardiopatas.

A seguir é possível apresentar uma tabela com as principais indicações e contraindicação para a prescrição do uso da alta frequência.

Tabela 1: Indicações e contraindicação da HF

\begin{tabular}{|c|c|c|c|c|}
\hline Autor(es) & Obra & Ano & Indicação da HF & $\begin{array}{l}\text { Contraindicação } \\
\text { da HF }\end{array}$ \\
\hline $\begin{array}{l}\text { ALMEIDA, } R . \\
\text { et al. }\end{array}$ & \begin{tabular}{ll}
\multicolumn{2}{l}{ Gerador de alta } \\
frequência & no \\
tratamento & de \\
lesão & por \\
pressão & em \\
idosos &
\end{tabular} & 2017 & $\begin{array}{l}\text { Tratamento de lesão } \\
\text { por pressão }\end{array}$ & - \\
\hline $\begin{array}{l}\text { BARROS; } \\
\text { SANTOS; } \\
\text { BORGES }\end{array}$ & $\begin{array}{l}\text { Tratamento de } \\
\text { verruga } \\
\text { ungueal } \\
\text { causada por } \\
\text { HPV com o uso } \\
\text { do gerador de } \\
\text { alta frequência: } \\
\text { relato de casos }\end{array}$ & 2007 & $\begin{array}{l}\text { Ação desinfectante, } \\
\text { antimicrobiana, } \\
\text { regeneração } \\
\text { tecidual da lesão da } \\
\text { lâmina ungueal }\end{array}$ & - \\
\hline BORGES & $\begin{array}{l}\text { Dermato- } \\
\text { funcional: }\end{array}$ & 2006 & $\begin{array}{lr}\text { Efeito } & \text { anti- } \\
\text { microbiano } & \text { sobre }\end{array}$ & - \\
\hline
\end{tabular}




\begin{tabular}{|c|c|c|c|c|}
\hline & $\begin{array}{l}\text { modalidades } \\
\text { terapêuticas } \\
\text { nas disfunções } \\
\text { estéticas }\end{array}$ & & 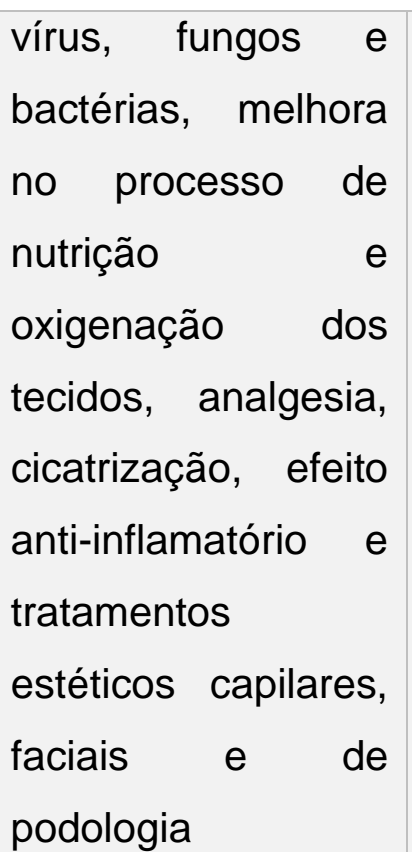 & \\
\hline $\begin{array}{l}\text { DA SILVA; } \\
\text { FARIA }\end{array}$ & $\begin{array}{l}\text { Uso de ondas } \\
\text { de alta } \\
\text { frequência no } \\
\text { tratamento de } \\
\text { onicomicose } \\
\text { comunicação } \\
\text { preliminar de } \\
\text { três casos }\end{array}$ & 2011 & $\begin{array}{l}\text { Estimular sistemas } \\
\text { antioxidantes } \\
\text { proteger contra os } \\
\text { radicais livres } \mathrm{e} \\
\text { melhorar } \\
\text { ventilação pulmonar }\end{array}$ & \\
\hline DAL GOBBO & $\begin{array}{l}\text { Estética facial } \\
\text { Essencial: } \\
\text { orientações } \\
\text { para } \\
\text { profissional de } \\
\text { estética }\end{array}$ & 2010 & $\begin{array}{l}\text { Tratamento de } \\
\text { transtornos } \\
\text { circulatórios, } \\
\text { desinfecção de } \\
\text { lesões infectadas, } \\
\text { por ter ação } \\
\text { bactericida } \\
\text { propriedade } \\
\text { antisséptica, } \\
\text { cauterização } \\
\text { pústulas, de }\end{array}$ & $\begin{array}{l}\text { Não usar gel ou } \\
\text { creme a base de } \\
\text { carbopol diluído } \\
\text { em álcool antes } \\
\text { do procedimento }\end{array}$ \\
\hline
\end{tabular}




\begin{tabular}{|c|c|c|c|c|}
\hline & & & $\begin{array}{l}\text { depilação, após } \\
\text { extração de } \\
\text { comedões, } \\
\text { tratamento do couro } \\
\text { cabeludo, pré e pós- } \\
\text { microdermoabrasão } \\
\text { pré- } \\
\text { galvanopuntura, } \\
\text { revitalização facial }\end{array}$ & \\
\hline $\begin{array}{l}\text { DEUSCHLE } \\
\text { et al. }\end{array}$ & $\begin{array}{l}\text { Caracterização } \\
\text { das lesões e } \\
\text { tratamentos } \\
\text { utilizados na } \\
\text { acne }\end{array}$ & 2015 & $\begin{array}{l}\text { Após extração dos } \\
\text { comedões para } \\
\text { prevenir infecções }\end{array}$ & - \\
\hline $\begin{array}{l}\text { HERNANDEZ } \\
; \quad \text { MERCIER- } \\
\text { FRESNEL }\end{array}$ & $\begin{array}{l}\text { Manual de } \\
\text { cosmetologia }\end{array}$ & 1999 & $\begin{array}{l}\text { Ação eletrosmótica } \\
\text { que pode por } \\
\text { osmose facilitar a } \\
\text { permeação de } \\
\text { substâncias nos } \\
\text { tecidos }\end{array}$ & - \\
\hline HIDROSUX & $\begin{array}{l}\text { Manual de alta } \\
\text { frequência da } \\
\text { HIDROSUX }\end{array}$ & $\begin{array}{l}{[201 ?} \\
]\end{array}$ & $\begin{array}{l}\text { Tratamentos faciais; } \\
\text { feridas inflamadas } \\
\text { pós-extração de } \\
\text { cutículas ungueais e } \\
\text { lesões podais; } \\
\text { desinfecção da pele } \\
\text { acneica; } \\
\text { cauterização da } \\
\text { pele pós-extração } \\
\text { de pústulas; } \\
\text { desinfecção do }\end{array}$ & $\begin{array}{l}\text { Portadores de } \\
\text { marca-passo; } \\
\text { portadores de } \\
\text { pinos ou placas } \\
\text { metálicas no local } \\
\text { da aplicação; } \\
\text { pessoas } \\
\text { cardíacas; } \\
\text { neoplasias; } \\
\text { gestantes; } \\
\text { pessoas com }\end{array}$ \\
\hline
\end{tabular}




\begin{tabular}{|c|c|c|c|c|}
\hline & & & $\begin{array}{l}\text { couro cabeludo no } \\
\text { caso de seborréias; } \\
\text { estimulação da } \\
\text { circulação } \\
\text { sanguínea facial e } \\
\text { capilar; pós- } \\
\text { depilação; úlceras } \\
\text { de pressão e feridas } \\
\text { abertas; facilitação } \\
\text { na permeação de } \\
\text { ativos; utilizado em } \\
\text { protocolos de } \\
\text { revitalização e } \\
\text { hidratação da pele. }\end{array}$ & $\begin{array}{l}\text { distúrbios de } \\
\text { sensibilidade; } \\
\text { epiléticos; } \\
\text { diabéticos } \\
\text { descompensados } \\
\text {; pele com } \\
\text { cosméticos } \\
\text { inflamáveis; ter } \\
\text { cuidado } \\
\text { pessoas } \\
\text { portadoras de } \\
\text { rosácea, ou que } \\
\text { tenham extrema } \\
\text { sensibilidade ao } \\
\text { calor. }\end{array}$ \\
\hline IBRAMED & $\begin{array}{l}\text { Instruções de } \\
\text { uso do } \\
\text { equipamento } \\
\text { de HF } \\
\text { IBRAMED }\end{array}$ & 2012 & 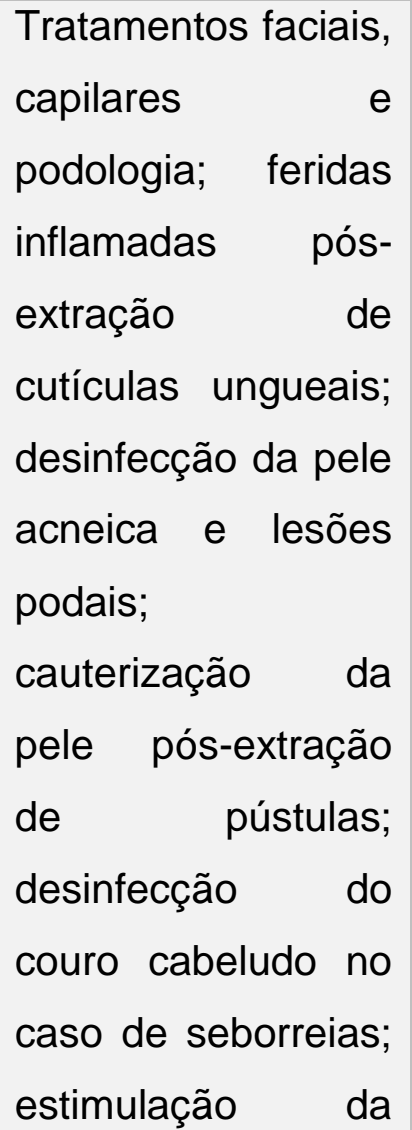 & $\begin{array}{l}\text { Não usar em } \\
\text { pessoas } \\
\text { cardíacas ou } \\
\text { portadoras de } \\
\text { dispositivos } \\
\text { eletrônicos } \\
\text { implantados } \\
\text { (marca-passo), } \\
\text { gestantes; } \\
\text { pessoas } \\
\text { problemas } \\
\text { ginecológicos, } \\
\text { pressão alta ou } \\
\text { diabetes } \\
\text { descompensada, } \\
\text { antecedentes }\end{array}$ \\
\hline
\end{tabular}




\begin{tabular}{|c|c|c|c|c|}
\hline & & & $\begin{array}{lr}\text { circulação } & \\
\text { sanguínea } & \text { facial } \\
\text { capilar; } & \text { pós- } \\
\text { depilação; } & \text { em } \\
\text { solução } & \text { de } \\
\text { continuidade } & \text { da } \\
\text { pele (úlceras } & \text { de } \\
\text { pressão e feridas } \\
\text { abertas); facilitação } \\
\text { na permeação } & \text { de } \\
\text { ativos; } & \text { em } \\
\text { protocolos } & \text { de } \\
\text { revitalização } & \text { e } \\
\text { hidratação da pele. }\end{array}$ & $\begin{array}{l}\text { cancerígenos, } \\
\text { pinos e placas no } \\
\text { local } \\
\text { aplicação, } \\
\text { problemas renais, } \\
\text { epilepsia } \\
\text { neoplasias; } \\
\text { pacientes com } \\
\text { diagnóstico de } \\
\text { trombose venosa } \\
\text { profunda; alergia } \\
\text { à corrente e ao } \\
\text { campo elétrico; } \\
\text { processos } \\
\text { infecciosos. }\end{array}$ \\
\hline KARELO & $\begin{array}{l}\text { Gerador de alta } \\
\text { frequência } \\
\text { como recurso } \\
\text { para } \\
\text { tratamento de } \\
\text { úlceras por } \\
\text { pressão: } \\
\text { estudo piloto }\end{array}$ & 2013 & $\begin{array}{l}\text { Cicatrização úlceras } \\
\text { de pressão e } \\
\text { diminuição de dor }\end{array}$ & - \\
\hline $\begin{array}{l}\text { MARCOS; } \\
\text { ELIAS; } \\
\text { PINHEIRO }\end{array}$ & $\begin{array}{l}\text { Aceleração do } \\
\text { processo } \\
\text { cicatricial com } \\
\text { uso do } \\
\text { aparelho alta } \\
\text { frequência no } \\
\text { PFS VIII Boa }\end{array}$ & 2013 & $\begin{array}{l}\text { A cicatrização em } \\
\text { pessoas com lesão } \\
\text { de primeira intenção }\end{array}$ & - \\
\hline
\end{tabular}




\begin{tabular}{|c|c|c|c|c|}
\hline & $\begin{array}{l}\text { Ventura de } \\
\text { Três Corações }\end{array}$ & & & \\
\hline $\begin{array}{l}\text { Marquetti; } \\
\text { ruaro; fréz }\end{array}$ & $\begin{array}{l}\text { Efeito do } \\
\text { gerador de alta } \\
\text { frequência no } \\
\text { crescimento } \\
\text { bacteriano in } \\
\text { vitro }\end{array}$ & 2018 & $\begin{array}{l}\text { Ação bactericida } \\
\text { sobre } \\
\text { Staphylococcus } \\
\text { aureus }\end{array}$ & - \\
\hline $\begin{array}{l}\text { MARTINS et. } \\
\text { al. }\end{array}$ & $\begin{array}{l}\text { Efeito } \\
\text { bactericida do } \\
\text { gerador de alta } \\
\text { frequência na } \\
\text { cultura de } \\
\text { Staphylococcu } \\
\text { s aureus }\end{array}$ & 2012 & $\begin{array}{l}\text { Ação bactericida } \\
\text { sobre } \\
\text { Staphylococcus } \\
\text { aureus }\end{array}$ & - \\
\hline MAUAD & $\begin{array}{l}\text { Estética } \\
\text { cirurgia } \\
\text { plástica: } \\
\text { tratamento no } \\
\text { pré e pós- } \\
\text { operatório }\end{array}$ & 2003 & $\begin{array}{l}\text { Pós-operatório da } \\
\text { abdominoplastia e } \\
\text { da rinoplastia em } \\
\text { virtude do auxílio da } \\
\text { oxigenação do } \\
\text { tecido e pelo seu } \\
\text { efeito bactericida }\end{array}$ & - \\
\hline $\begin{array}{l}\text { OLIVEIRA; } \\
\text { PEREZ }\end{array}$ & $\begin{array}{l}\text { Estética Facial: } \\
\text { Curso Didático } \\
\text { de Estética }\end{array}$ & 2008 & $\begin{array}{l}\text { Ação bactericida e } \\
\text { antisséptica } \\
\text { melhora do trofismo } \\
\text { dérmico }\end{array}$ & $\begin{array}{l}\text { Marca-passo } \\
\text { cardíaco, } \\
\text { alterações de } \\
\text { sensibilidade, } \\
\text { pele com } \\
\text { produtos } \\
\text { inflamáveis, } \\
\text { neoplasias }\end{array}$ \\
\hline
\end{tabular}




\begin{tabular}{|c|c|c|c|c|}
\hline & & & & $\begin{array}{l}\text { (câncer) } \\
\text { gestantes }\end{array}$ \\
\hline OLIVEIRA & $\begin{array}{l}\text { Utilização do } \\
\text { ozônio através } \\
\text { do aparelho de } \\
\text { alta frequência } \\
\text { no tratamento } \\
\text { da úlcera por } \\
\text { pressão }\end{array}$ & 2011 & $\begin{array}{l}\text { Ação bactericida, } \\
\text { antisséptica e anti- } \\
\text { inflamatória, as } \\
\text { quais podem } \\
\text { beneficiar } \\
\text { reparação tecidual, } \\
\text { tratamento de vários } \\
\text { tipos de lesões } \\
\text { cutâneas, dentre } \\
\text { elas a úlcera de } \\
\text { pressão. }\end{array}$ & - \\
\hline $\begin{array}{l}\text { Pereira Sá et } \\
\text { al. }\end{array}$ & $\begin{array}{l}\text { Estudo } \\
\text { comparativo da } \\
\text { ação do laser } \\
\text { GaAllnP e do } \\
\text { gerador de alta } \\
\text { frequência no } \\
\text { tratamento de } \\
\text { feridas } \\
\text { cutâneas em } \\
\text { ratos: estudo } \\
\text { experimental }\end{array}$ & 2010 & $\begin{array}{l}\text { Tratamento de } \\
\text { feridas cutâneas e } \\
\text { abreviação do } \\
\text { processo cicatrical }\end{array}$ & - \\
\hline PEREIRA & $\begin{array}{l}\text { Eletroterapia } \\
\text { sem mistérios: } \\
\text { aplicações em } \\
\text { estética facial e } \\
\text { corporal }\end{array}$ & 2007 & $\begin{array}{l}\text { Germicida } \\
\text { bactericida }\end{array}$ & - \\
\hline
\end{tabular}




\begin{tabular}{|c|c|c|c|c|}
\hline Rodrigues & $\begin{array}{l}\text { Efetividade da } \\
\text { alta frequência } \\
\text { nas acnes } \\
\text { vulgaris graus I } \\
\text { e II }\end{array}$ & 2014 & $\begin{array}{l}\text { Tratamento das } \\
\text { acnes vulgaris de } \\
\text { graus I e II }\end{array}$ & - \\
\hline $\begin{array}{l}\text { SANTOS; } \\
\text { GUIMARÃES }\end{array}$ & $\begin{array}{l}\text { Tecnologia em } \\
\text { estética. Curso } \\
\text { Didático de } \\
\text { Estética }\end{array}$ & 2008 & $\begin{array}{l}\text { Limpeza de pele, } \\
\text { terapia capilar } \\
\text { melhorando a } \\
\text { circulação do couro } \\
\text { cabeludo, } \\
\text { cicatrização das } \\
\text { lesões originadas } \\
\text { pelas acnes, } \\
\text { beneficia o processo } \\
\text { de reparação da } \\
\text { pele, e facilita a } \\
\text { ionização indireta de } \\
\text { substâncias, como } \\
\text { ampolas aquosas } \\
\text { nutritivas a base de } \\
\text { colágeno }\end{array}$ & - \\
\hline SCHUH & $\begin{array}{l}\text { Associação da } \\
\text { alta frequência, } \\
\text { laser de baixa } \\
\text { potência e } \\
\text { microcorrentes } \\
\text { no tratamento } \\
\text { da lesão por } \\
\text { pressão }\end{array}$ & 2017 & $\begin{array}{l}\text { Tratamento do } \\
\text { reparo tecidual em } \\
\text { lesão por pressão }\end{array}$ & - \\
\hline $\begin{array}{l}\text { SILVA; } \\
\text { PEREIRA }\end{array}$ & $\begin{array}{l}\text { Avaliação } \quad \text { e } \\
\text { tratamento }\end{array}$ & 2018 & $\begin{array}{l}\text { Tratamento da pele } \\
\text { acneica para obter }\end{array}$ & - \\
\hline
\end{tabular}




\begin{tabular}{|c|c|c|c|c|}
\hline & $\begin{array}{l}\text { estético da } \\
\text { acne vulgar }\end{array}$ & & $\begin{array}{l}\text { efeito } \\
\text { antibactericida, } \\
\text { antifungicida } \\
\text { antiséptico, reduzir } \\
\text { as lesões } \\
\text { inflamatórias, } \\
\text { diminuir a } \\
\text { oleosidade da pele }\end{array}$ & \\
\hline ZHANG et al. & $\begin{array}{l}\text { Increased } \\
\text { growth factors } \\
\text { play a role in } \\
\text { wound healing } \\
\text { promoted by } \\
\text { noninvasive } \\
\text { oxygenozone } \\
\text { therapyin } \\
\text { diabetic } \\
\text { patients with } \\
\text { foot ulcers }\end{array}$ & 2018 & $\begin{array}{l}\text { Tratamento de } \\
\text { úlceras do pé } \\
\text { diabético }\end{array}$ & - \\
\hline
\end{tabular}

Fonte: o autor, 2019.

Alguns cuidados são necessários, dentre eles:

- os aparelhos geradores de alta frequência deverão estar afastados a cerca de 6 metros de outros aparelhos de corrente galvânica ou corrente farádica, se forem utilizados concomitantemente, pois há casos de atendimentos por mais de um profissional em cabines muito próximas. Lembrando que os cabos de outros aparelhos podem agir como antenas, captando as ondas eletromagnéticas produzidas pelos aparelhos de alta frequência e isto pode danificar o aparelho e/ou gerar algum perigo para o cliente sob tratamento; 
- é recomendado que o aparelho de alta frequência seja submetido a uma inspeção e manutenção preventiva em postos técnicos a cada 12 meses de utilização (IBRAMED, 2012);

- a conexão entre o eletrodo e o porta-eletrodo não deve tocar a pele do cliente, pois ele poderá sentir um choque elétrico muito forte. Também o profissional não deve jamais encostar-se a essa conexão;

- cliente não poderá receber o tratamento se a região estiver molhada ou úmida.

\section{METODOLOGIA}

O estudo foi baseado em pesquisa bibliográfica explicativa e qualitativa e pode ser caracterizado da seguinte forma:

Pesquisa bibliográfica porque foi elaborada a partir de livros, artigos e material já publicado concernente ao emprego da alta frequência em estética e terapia.

A pesquisa bibliográfica é feita a partir do levantamento de referências teóricas já analisadas, e publicadas por meios escritos e eletrônicos, como livros, artigos científicos, páginas de web sites. Qualquer trabalho científico inicia-se com uma pesquisa bibliográfica, que permite ao pesquisador conhecer o que já se estudou sobre o assunto. Existem, porém pesquisas científicas que se baseiam unicamente na pesquisa bibliográfica, procurando referências teóricas publicadas com o objetivo de recolher informações ou conhecimentos prévios sobre o problema a respeito do qual se procura a resposta. (FONSECA, 2002, p. 32)

Ela foi explicativa visto que explicou os fenômenos fisiológicos que resultam em benefícios orgânicos em uma pessoa submetida ao tratamento com equipamento de alta frequência. Logo, tratou-se indiscutivelmente de buscar o motivo pelo qual um fenômeno aconteceu.

A pesquisa explicativa "... têm como preocupação central identificar os fatores que determinam ou que contribuem para a ocorrência dos fenômenos. Este é o tipo de 
pesquisa que mais aprofunda o conhecimento da realidade, porque explica a razão, o porquê das coisas." (GIL, 2007, p. 42).

Foi qualitativa, pois não requereu o uso de métodos e técnicas estatísticas, logo ela se preocupou com aspectos da realidade que não podem ser quantificados, centrando-se na compreensão e explicação da dinâmica dos fenômenos observados.

A pesquisa quantitativa, que tem suas raízes no pensamento positivista lógico, tende a enfatizar o raciocínio dedutivo, as regras da lógica e os atributos mensuráveis da experiência humana. Por outro lado, a pesquisa qualitativa tende a salientar os aspectos dinâmicos, holísticos e individuais da experiência humana, para apreender a totalidade no contexto daqueles que estão vivenciando o fenômeno. (POLIT; BECK; HUNGLER, 2004, p. 201).

O estudo concernente ao tema foi realizado através da análise sistemática de livrostexto da área de Fisioterapia Dermato-funcional e de Estética que abarcaram o assunto em questão. Foi realizada busca nas bases de dados de informação em saúde: Europa PMC, Pubmed/Medline, Lilacs, Scielo e Google Acadêmico utilizando como unitermos as seguintes palavras-chave: alta frequência, ozonioterapia, alta frequência+cicatrização, alta frequência+bactericida nas bases de dados em português e high frequency, ozonotherapy, high frequency + cicatrization, high frequency + bactericide nas bases de dados em inglês.

\section{CONSIDERAÇÕES FINAIS}

O gerador de alta frequência é um aparelho de fácil acessibilidade aos profissionais de estética e fisioterapia, além de ser simples de manuseio e com amplas aplicações no mundo da estética e terapia.

A alta frequência permite benefícios ímpares, tais como: aceleração no processo de cicatrização de feridas cutâneas; efeito antimicrobiano sobre vírus, fungos e bactérias; melhora da oxigenação e nutrição tissular graças ao seu efeito vasodilatador 
superficial; efeito anti-inflamatório e analgésico; facilita a permeação de alguns ativos cosméticos, como as ampolas aquosas nutritivas à base de colágeno, elastina, uréia, extratos placentários via cutânea.

As técnicas de aplicação são a fluxação, fulguração e os faiscamentos diretos e indiretos. Todas as técnicas são de extrema facilidade de aplicação e sem aumento de custos financeiros. Quanto às indicações da alta frequência, elas vão desde a terapia, estética facial, estética corporal até a estética capilar. Já as contraindicações incluem hipertensos arteriais ou diabéticos descompensados, epiléticos, pessoas com marca-passo cardíaco ou implante metálico local, distúrbios de sensibilidade, pele com cosméticos inflamáveis (álcool e éter), pessoas com câncer e gestantes.

Conclui-se que a terapia por alta frequência pode agregar valor aos procedimentos estéticos e fisioterapêuticos, embora não seja o único procedimento a ser empregado e sim parte de um conjunto de estratégias terapêuticas. Constatou-se a carência de estudos atualizados concernentes ao tema abordado e recomenda-se que novos estudos sejam implementados para verificar outras aplicabilidades desse recurso terapêutico e estético.

\section{REFERÊNCIAS BIBLIOGRÁFICAS}

ALMEIDA, R. et al. Gerador de alta frequência no tratamento de lesão por pressão em idosos. Rev enferm UFPE on line., Recife, v.11, n.8, p.3136-42, ago., 2017.

BARROS, V.C.C; SANTOS, V.N.S; BORGES, F.S. Tratamento de verruga ungueal causada por HPV com o uso do gerador de alta frequência: relato de casos. Revista de Especialização em Fisioterapia. v. 1, n.2, out/Nov/dez. 2007.

BORGES, F.S. Alta frequência. In: Borges, F.S. Dermato-funcional: modalidades terapêuticas nas disfunções estéticas. São Paulo: Phortes, 2006.

Calunga, J.L.; et al. Terapia de ozônio retal em pacientes com enfisema pulmonar. Revista Médica de Chile. v.139, n.4, p. 439-447, 1 abr. 2011. 
DA SILVA, J.L.M.; FARIA, D.P. Uso de ondas de alta frequência no tratamento de onicomicose comunicação prelimilar de três casos. An. Bras. Dermatol. Rio de Janeiro, v. 86, n.3 maio/Jun. 2011.

DAL GOBBO, P. Estética facial Essencial: orientações para profissional de estética. São Paulo: Atheneu, 2010.

DEUSCHLE, V. C. K. N. et al. Caracterização das lesões e tratamentos utilizados na acne. Revista Interdisciplinar de Ensino, Pesquisa e Extensão. v. 3 n. 1, 2015. Disponível em: http://revistaeletronica.unicruz.edu.br/index.php/eletronica/article/view/224236/pdf_52. Acesso em: 1 dez. 2018.

FONSECA, J. J. S. Metodologia da pesquisa científica. Fortaleza: UEC, 2002. Apostila.

GIL, A. C. Como elaborar projetos de pesquisa. 4. ed. São Paulo: Atlas, 2007.

HERNANDEZ, M.; MERCIER-FRESNEL, M.M. Manual de cosmetologia. 3 ed. Rio de Janeiro: Revinter, 1999.

HIDROSUX. Manual de alta frequência da HIDROSUX. Paraná: MR Luiz - Aparelhos Estéticos, [201?]. Disponível em: https://cdn.awsli.com.br/276/276415/arquivos/Manual\%20-20Alta\%20frequencia.pdf Acesso em: 4 mar. 2019.

IBRAMED. Instruções de uso do equipamento de HF IBRAMED. 2 ed. São Paulo: [s/Ed.], 2012. Disponível em: https://manualzz.com/doc/5917650/hf-ibramed. Acesso em: 4 mar. 2019.

KARELO, R.I.G. Gerador de alta frequência como recurso para tratamento de úlceras por pressão: estudo piloto. Fisioter. Mov., Curitiba, v. 26, n. 4, p. 715-724, set./dez. 2013. 
MARCOS, T.G.; ELIAS, J.P.C; PINHEIRO, F.A.M. Aceleração do processo cicatricial com uso do aparelho alta frequência no PFS VIII Boa Ventura de Três Corações. XV Encontro de Iniciação Científica da UninCor. Três Corações/MG: Universidade do Rio Verde, nov. 2013.

Marquetti, M.G.K.; ruaro, j.a.; fréz, a.r. Efeito do gerador de alta frequência no crescimento bacteriano in vitro. Congresso Brasileiro de Fisioterapia Dermatofuncional. Modalidade Pôster. Recife, 8 a 10 de nov, 2012. Disponível em: http://www.abrafidef.org.br/downloadDoc.php?d=arqAnais\&f=EFEITO_DO_GERADO R_DE_ALTA_FREQUENCIA_MARIA_DA_GLORIA_MARQUETTI.pdf. Acesso em: 1 dez. 2018.

MARTINS, A. et. al. Efeito bactericida do gerador de alta frequência na cultura de Staphylococcus aureus Fisioterapia e Pesquisa. São Paulo, v.19, n.2, p. 153-157, Apr. /jun. 2012.

MAUAD, R. (Org). Estética e cirurgia plástica: tratamento no pré e pós-operatório. 2. ed. São Paulo: Senac, 2003.

OLIVEIRA, A. L.; PEREZ, E. Estética Facial: Curso Didático de Estética. v. 2. São Caetano do Sul, SP: Yendis, 2008.

OLIVEIRA, L.M.N. Utilização do ozônio através do aparelho de alta frequência no tratamento da úlcera por pressão. Revista Brasileira de Ciências da Saúde. Paraíba, v.9. n. 30, p. 41-46, Dez, 2011.

Pereira Sá, H.; et al. Estudo comparativo da ação do laser GaAllnP e do gerador de alta frequência no tratamento de feridas cutâneas em ratos: estudo experimental. Conscientiae saúde, São Paulo, v. 9, n. 3, p.360-366, 2010.

PEREIRA, F. Eletroterapia sem mistérios: aplicações em estética facial e corporal. Rio de Janeiro: Rubio, 2007. 
POLIT, D.F.; BECK, C.T.; HUNGLER, B.P. Fundamentos de Pesquisa em Enfermagem: métodos, avaliação e utilização. 5 ed. Porto Alegre: Artmed, 2004.

ROBINSON, A.J.S. Eletrofisiologia clínica. 2 ed. Porto Alegre: Artmed, 2000.

Rodrigues, D.C. Efetividade da alta frequência nas acnes vulgaris graus I e II. Relato de caso. EFDeportes.com, Revista Digital. Buenos Aires, a. 19, n. 195, ago. 2014.

SANTOS, B. M.; GUIMARÃES, C. C. Tecnologia em estética. In: LACRIMANTI, L.,M. (Coord.). Curso Didático de Estética. São Caetano do Sul, SP: Yendis, v.2, cap.5, p.111-123, 2008.

SCHUH, C. M. Associação da alta frequência, laser de baixa potência e microcorrentes no tratamento da lesão por pressão. Cinergis. Santa Cruz do Sul, 18(2):99-103, abr.jun. 2017.2 Disponível em: https://online.unisc.br/seer/index.php/cinergis/article/view/8490/5878. Acesso em: 1 dez. 2018.

SILVA J.A.C.; PEREIRA, P.C. Avaliação e tratamento estético da acne vulgar. Revista Científic@ Universitas. Itajubá v.5, n.1, p.114-123 Jan-jul. 2018.

SORIANO, M.C.D.; PÉREZ, S.C.; BAQUÉS, M.I.C. Eletroestéstica Profissional Aplicada: teoria e prática para a utilização de correntes em estética. Barcelona: Sorisa, 2002.

The Editors of Encyclopaedia Britannica. Encyclopaedia Britannica. UNITED KINGDOM, London, $2018 . \quad$ Disponível em: https://www.britannica.com/biography/Werner-von-Siemens. Acesso em: 20 nov. 2018.

Zhang J. et al. Increased growth factors play a role in wound healing promoted by noninvasive oxygenozone therapyin diabetic patients with foot ulcers. Oxid Med Cell 
Longev. n.1, p.1-8, Jun, $2014 . \quad$ Disponível em:

https://www.ncbi.nlm.nih.gov/pubmed/25089169. Acesso em: 27 nov. 2018.

Enviado: Abril, 2019.

Aprovado: Junho, 2019. 